\title{
The Multiannual Financial Framework of the European Union: A Political Power Game
}

\begin{abstract}
By Auke R. Leen ${ }^{*}$
The present multiannual financial framework (MFF) 2014-2020 of the European Union (EU) is the first long-term budgetary framework of the Union under the Treaty of Lisbon. The MFF has been called a political power game between the institutions of the Union. This paper looks at the financial effects of the new MFF caused by the changing financial powers under the new Treaty. The two guiding questions are: (1) What does the MFF, or more in general a fiscal rule, look like?; and (2) Does the MFF really constrain the EU budget? The paper shows the results of the constitutional/political power game within the new framework. In general it can be said that the key to understanding the outcome of the negotiations is flexibility: increased flexibility of the existing budget and new flexible off-budget expenses. Accounting, disguised as flexibility measures, has become a form of transparent budget gimmickry: although the new MFF is nominally lower than its predecessor, Member States in fact have to pay more.
\end{abstract}

Keywords: constitutional economics, creative accounting multiannual financial framework of the European Union

\section{Introduction}

The current Multiannual Financial Framework (MFF) (formerly called "financial perspective") (European Commission 2013a) is the first framework that is based on the Treaty of Lisbon that entered into force on December 1, 2009. Article 312(1) of the Lisbon Treaty, as the Treaty on the Functioning of the European Union (TFEU) is known, states that "[t]he "annual budget of the Union shall comply with the multiannual financial framework". The MFF is the long-term budgetary framework within whose limits the annual budgets for the EU must be set. As stated by the European Commission (2011), the EU's executive arm, the MFF "is not the budget of the EU for seven years. It is a mechanism for ensuring that EU spending is predictable and at the same time subject to strict budgetary discipline". On the basis of political priorities it defines the maximum amounts available for each major spending. It is also both a political and budgetary framework. Within the limits of the framework, the European Parliament (EP) and the Council of the European Union (Council of Ministers or Council, representing the governments of the 28 Member States), which are the Union's budgetary authorities, have to agree each year on the budget for the following year.

\footnotetext{
${ }^{*}$ Leiden University, Department of Tax Law and Economics, The Netherlands.
} 
Prior to 2009 the MFFs had no legal basis in the Treaties. ${ }^{1}$ The first framework, for the period 1988-1992, was based on an Inter-Institutional Agreement (IIA) between the Council, Commission and EP.

The MFF has been called a political power game among the EU institutions (Dhéret et al. 2012: 6). This paper discusses the results of the constitutional/political power game within the new framework, the so-called MFF package. ${ }^{2}$ What are the budgetary results of the changing financial powers of the new Treaty? The two guiding questions are: (1) What does the MFF, or more in general a fiscal rule, look like?; and (2) Does the MFF really constrain the EU budget? ${ }^{3}$ In other words, is there sufficient political commitment to pursue a disciplined policy or is creative accounting the name of the game?

The paper first looks at the reasons behind the fiscal rules and their history, and gives a taxonomy of fiscal rules and their effect on the performance of governments. Next we discuss the history and general constitutional rules of the MFF. Subsequently we look at the changing political powers before and after the Lisbon Treaty. The paper concludes with presenting and assessing the budgetary effects of the new MFF package.

\section{Fiscal Rules}

The IMF defines a fiscal rule as a "permanent constraint on fiscal policy through simple numerical limits on budgetary aggregates" (IMF 2009: 4). A fiscal rule delineates a numerical target with a view to guiding fiscal policy. It specifies a summary operational fiscal indicator and it can be readily operationalized, communicated and monitored. In short, fiscal rules should be simple and well-defined (cp. Schuknecht 2004, Debrun et al. 2008). Fiscal (budget) rules, however, do also refer to a wide range of fiscal institutions. "Even the institutions that legislatures use to prepare budgets, and the structure of committees through which budget deliberations must proceed, can be viewed as budget rules" (Poterba 1996: 4). For this reason we also consider the MFF to be a fiscal rule. Commonly, fiscal rules or, more in general, rulesbased fiscal responsibility frameworks can be considered a form of incomplete constitutional contracts (Buchanan 2000). We are looking at rules, like the

\footnotetext{
1 Their legal significance, however, was considered to be more than a simple political commitment. The reason for this is that financial perspectives were concluded by institutions that can enter into legal obligations under the powers conferred upon them by the Treaties. The agreements were therefore consistent with the provisions of the Treaties.

The Lisbon Treaty requires that the MFF is set out in a regulation. A regulation is a law that is applicable and binding in all Member States directly, whereas inter-institutional agreements are binding for the contracting parties only.

${ }^{2}$ For an overview of the political power game itself and the political horse trading that went with it, see European Parliament, 2013, Focus.

${ }^{3}$ At present the MFF totals 959 billion euro in spending commitments (1.03\% of total GNI of the Member States) and 908 billion euro in actual payments ( $0.98 \%$ of GNI).
} 
MFF, that are designed at the contractual/constitutional level and will be executed later at the post-constitutional contractual level.

\section{The Reasons behind Fiscal Rules}

But first, why are fiscal rules or, more in general, rules-based fiscal responsibility frameworks necessary at all? They are there to safeguard against the deficit bias and excessive spending of governments. The first reason for this is governments' supposed shortsightedness (IMF 2009). Concerns about electoral prospects may lead to insufficient attention to longer-term requirements: governments opportunistically raise spending or cut taxes to increase their chances of reelection. In short, public debt and spending become instrumental for obtaining political power or remaining in power. Secondly, the "common pool problem" has been mentioned. This problem occurs since special interest groups or constituencies do not consider the overall budgetary impact of their financial demands. Debt and spending take on the role of political mollifiers. Moreover, the larger the group of people who have direct access to the political decision-making process, the more their goals will diverge and the more debt and/or spending is needed to form a common government policy (Blankart 1996: 64). In general, it can also be said that authoritarian institutions that centralize power in the hands of only a small group of people, are more likely to pursue tight fiscal policies than collegial institutions that disperse power and require consensus for budget enactment (Poterba 1996: 44-46). Obviously, the Union belongs to the latter group of institutions.

For those who do not perceive a government as selfish and prone to misusing public debt, the situation is obviously different. To them a benevolent government acts as an authority that generally uses its instruments to the best. The negative view, however, seems particularly fit for the Union. For what to think of a budget decision where, for instance, a member of the EP (MEP) from Romania decides about money from the Netherlands to be spent on someone living in Italy? Would it not be safe to say that an MEP will have less incentive to look for the common good than a member of national parliament, for example? (cp. Friedman 1980: 146). Even more than that, the present situation is characterized by a lack of trust and by fears of free-riding between Member States themselves and between Member States and EU institutions. As far as the policies of the Member States go, the Union's budgetary process can probably be best described as a vetocracy, "as a war of 'red lines', leaving all responsibility for achieving a coherent outcome to selected 'brokers'" (Benedetto 2012: 172).

Consequently, a strong commitment to fiscal sustainability is needed. The introduction of the MFF, following the already existing explicit fiscal rules, complements the Union's fiscal constitution. The philosophy behind the introduction of subsequent fiscal rules shows the necessity of the different steps in the evolution of Europe's fiscal constitution. ${ }^{4}$

\footnotetext{
${ }^{4}$ It remains to be seen, though, if a government really wants to be constrained, since selfbinding is the essence of constitution-making. Maybe it is just the other way around: "[i]n politics, people never try to bind themselves, only to bind others" (Elster 2000: ix).
} 


\section{Fiscal Rules in History}

The virtue of fiscal rules was already heralded by the Romans: "The budget should be balanced, the treasury should be refilled, public debt should be reduced" (Cicero 63 BC, Kopits 2001: 3).

Formal attempts to do so, however, only date back to the last century and a half. Three waves of fiscal rules can be distinguished (Kopits 2001: 4-5). In the first wave, which began in the 1920s, the so-called golden rule was prescribed. Subnational governments in federal systems, for instance in the U.S. and Switzerland, had to maintain a current budget balance that was net of investment expenses. In the second wave, after World War II, industrial countries such as Germany, Italy and the Netherlands introduced balancedbudget rules. Most of them were of the golden rule type. In the third and current wave, in contrast to the previous waves, fiscal rules are supported by transparency standards and appropriate accounting conventions. In general, these elements are enshrined in broad legislation or international treaties, for instance in New Zealand, Brazil and the EU Member States ${ }^{5}$.

Specifically, the most important rules promoting fiscal sustainability are: (1) Budget balance rules (e.g., overall, structural, cyclically adjusted or primary balance). None of these rules, however, have any influence on government size; they only affect debt sustainability and/or economic stabilization. (2) Debt rules that set an explicit limit or target for public debt as a percentage of GDP. These rules are effective in terms of ensuring convergence to a debt target but have no influence on the size of the government either. (3) Expenditure rules that set limits on spending in absolute terms or growth rates as a percentage of GDP. They limit the size of the government, but do not constrain the revenue side. (4) Revenue rules that set ceilings or floors on revenue.

\section{The Results of Fiscal Rules}

As mentioned, over time an increasing number of countries have moved away from a single rule toward a combination of rules that are closely linked to debt sustainability and, more recently, also curtail the size of the government. ${ }^{6}$ In many cases these rules were introduced as part of broader reforms aimed at strengthening the framework for fiscal policy. These include strong transparency requirements and public oversight (mandatory publication of regular reports that must contain multiyear fiscal projections and other predetermined disclosures), effective budget mechanisms, legislated overall principles that guide the formulation of fiscal policy, and the introduction of independent fiscal agencies (IMF 2009).

These broader reforms are important in view of the effects of fiscal rules on creative accounting. At one extreme, the "institutional irrelevance view"

\footnotetext{
${ }^{5}$ For the EU the goal of transparency is still far from being realized. Recently it was said that "the EU's budget and budgetary procedures are beyond Byzantine" (King 2014). King also states that the "opaque" and "unintelligible" budget is beyond the control of the political process but in the hands of EU civil servants.

${ }^{6}$ Intergenerational equity, for instance, requires the build-up of public assets from the proceeds of exhaustible natural resources.
} 
holds "that budget rules can be circumvented by modifying accounting practices and changing the nominal timing or other classification of taxes and expenditures" (Poterba 1996, Eastery 1999). As we will see, for the EU the stated effects are not imaginary.

On the other hand, empirical studies (Hagen and Harden 1995, Debrun et al. 2008, IMF 2009) suggest that fiscal rules do improve fiscal performance: a stronger cyclically adjusted primary balance is effective (the relationship in terms of public debt-to-GDP ratios is weaker, though); budget balance and debt rules are better than expenditure rules; higher levels of government have been associated with more fiscal discipline; and a strong legal basis and strict enforcement of rules are important.

Fiscal rules also increase the probability of accurate budget projections (Luechinger and Schaltegger 2013: 785). In the past, projections by finance ministers were generally overly pessimistic. Fiscal rules, however, could also create incentives to make overly optimistic projections in order to postpone politically disputed budget cuts. As far as creative accounting, windowdressing or other ways of circumventing fiscal rules goes, however, it appears that fiscal rules lower the probability of projected and realized deficits significantly.

\section{The Mff: History and Content}

During the 1980s the annual budget negotiations were plagued by a continuous stalemate between the Council ${ }^{7}$ and the European Parliament. At several instances between 1980 and 1985, the Parliament rejected the proposed budget. A fundamental reform of the Community's budgetary procedure was required. $^{8}$ In 1988, an inter-institutional agreement between the Council, Commission and EP enabled the two arms of the budgetary authority to make decisions in advance for a period of several years. ${ }^{9}$ As predecessors of the current MFF, so-called "financial perspectives" were introduced. They set out the priorities for a five to seven-year period and were made for the years 19881992 (the "Delors I Package"); 1993-1999 (the "Delors II package"); 20002006 (Agenda 2000); 2007-2013; and 2014-2021 (the present framework). The

\footnotetext{
${ }^{7}$ In this paper we do not discuss differences within the Council. In fact, there are differences between EU Member States or groups of EU states such as the Northern vs. the Southern groups. For the history of opposing views on the Member States' current fit-for-all $1 \%$ contribution of their national GNI to the Union (linking Member States' budget contributions more closely to their level of relative prosperity), see European Commission, 2014 (cp. Campanella 2011).

${ }^{8}$ For the change in power with regard to the annual budgetary procedure under the Lisbon Treaty, see Benedetto 2012: 47-48. It should be noted that negotiations about the MFF for 2014-2020 have taken place in tandem with a debate on the future shape of the Common Agricultural Policy (CAP) (op.cit.: 103). For a discussion of the CAP reform, the Lisbon Treaty and the MFF, see op. cit., pp. 103-121). The conclusion is that "[e]ssentially the decision rules and institutional structure around the CAP, including the balance of forces between member states, still ensure that change will be incremental" (op.cit.: 121).

${ }^{9}$ Nevertheless, the EP rejected the annual budget for 2011 .
} 
existing seven-year budget is for a total of Euro 959 billion in spending commitments, the so-called ceilings on commitment appropriations, and Euro 908 billion in actual payments, the so-called ceilings on payment appropriations (both are in 2011 prices).

The MFF fixes the amount and composition of the EU expenditure over the following years. It ensures adequate financing for projects extending over several years, improves financial discipline, and establishes objectives from the outset. The annual budgetary procedure then determines the exact level of expenditure and the breakdown of expenditure between headings for the year in question (Nello 2012).

Article 312 of the TFEU (Part Six, Title II, Chapter 2) on the MFF states (paraphrased) the following five points:

1. The MFF shall ensure that the Union expenditure develops in an orderly manner and within the limits of its own resources. It shall be established for a period of at least five years. The annual budget shall comply with the MFF.

2. The Council shall adopt a regulation laying down the MFF. The Council shall act unanimously after obtaining the consent of the EP which shall be given by a majority of its component members. However, unanimously the Council can adopt a decision to act by qualified majority when adopting the regulation.

3. The MFF determines the amounts of the annual ceilings by category and lays down any other provision required for the annual budgetary process.

4. Where no Council regulation has been adopted, last year's framework shall apply.

5. The EP, Council and Commission shall work together to facilitate the adoption of the MFF.

The MFF is also the constitutional framework alongside the already existing fiscal rules on a balanced budget (Art. 310) ${ }^{10}$ and the limitations on own resources (Art. 311). Specifically, a decision has to be made regarding the so-called MFF package: the MFF regulation (MFFR) (European Council 2013a) and an Inter-institutional Agreement (IIA) (European Council 2013b). ${ }^{11}$ In addition, the new MFF package includes declarations on, for instance, own resources, youth unemployment and the review/revision of the MFF (European Commission 2013a). In summary, decisions are made in the package regarding the expenditure side (the MFF) as well as the revenue side (the decision on

\footnotetext{
${ }^{10}$ At the moment, the EU budget plays no discretionary role in economic policy. If that would be the case it would be much harder to balance the budget, as is presently required: a zerostructural-deficit rule would be needed, as is already required for the Member States by the new stability and growth pact. It would be hard to obtain reliable data, though.

${ }^{11}$ The IIA contains some residual aspects that were originally included in the financial perspectives (the old IIA), but not in the MFF.
} 
own resources). The national governments, however, are still fully responsible for raising the revenue.

\section{The MFF: Polictical Enforcement Before and After the Lisbon Treaty}

As stated, the MFF "is a real 'political power game' where each institution tries to make final agreements, as much as possible, in line with its own views" (Dhéret 2012). How did the procedures regarding the MFF change before and after the Lisbon Treaty?

Before the Treaty, the Commission and Council would agree on the longterm budget. Member States would then reach an accord unanimously. The EP had the right of veto. The three institutions could set an amendable ceiling for expenditure to allow for some flexibility if need be, i.e. in the event of a recession or natural disaster. EU revenue was capped at a maximum level. Article 312(3) of the new treaty, however, sets an absolute ceiling on spending. This limits the flexibility of the annual budget.

Before the new Treaty there was room for a maximum and actual rate of increase in the budget, to be agreed annually by the Commission, Council and EP. After Lisbon, the MFF sets the maximum rate of increase and the Treaty does not foresee increases.

With respect to the decision-making regarding own resources, the EP has gained the power of consent for the implementation of any changes to the own resources (Art. 311 TFEU). Based on a proposal by the Commission, the Council still unanimously decides on changes to the own resources after consulting the EP. The changes are to be approved by the Member States in accordance with their respective constitutional requirements.

Can the fiscal rules be enforced? In general it can be said that fiscal rules invite abuse through creative accounting practices to circumvent the rules. One of the most effective ways, however, to guarantee the enforcement of fiscal rules is to make strict transparency an integral part of these rules. There should be transparency in institutional structure and in fiscal reporting. In general, the Commission, Council and EP benefit from a "collective efficiency and legitimacy gain" (Benedetto 2012: 41) by the simplified and easier to understand budgetary procedures of the Lisbon Treaty. If so, creative accounting should be diminished.

\section{Assessment of the MFF Package}

The positive or negative assessment of the new MFF package is of course related to one's point of view. If a government is anxious to avoid criticism for its acceptance of EU empowerment, for instance, it will downplay the changes in the new Treaty. It is also important how one sees the effects and purpose of the EU budget. Is it purely redistributory in nature or does it deliver sidepayments to secure European integration? Does it have benevolent objectives, 
e.g., spending for regional development, or has the budget to be increased because of substantial new tasks such as foreign policy, R\&D and the improvement of infrastructure?

In any case, the question becomes: Has the very real rebalancing of the budgetary powers of the EU institutions in terms of agenda setting and vetoes changed the outcomes of the MFF package decision process? (cp. Benedetto 2012: $55-56) .^{12}$

\section{The Constitutionalisation of the MFF}

The constitutionalisation of the MFF is one of the major changes introduced by the Lisbon Treaty. It is about the strongest commitment one can make towards fiscal sustainability. Since a Treaty change is required, it will be very hard to change the MFF under tempting situations. There is a real loss of flexibility: after the Lisbon Treaty, the MFF has become more difficult to amend. The new MFF also maximizes the reputational costs for those institutions of the Union that do not adhere to it. In short, budget flexibility, such as the introduction of higher spending ceilings or ad hoc policies, will be diminished for the Commission, Council and European Parliament. At first sight, it also seems as if the MFF means a real loss of power for those in favor of budget flexibility.

\section{The Abolishment of National Ratification and a Ceiling on Spending}

The abolishment of the cumbersome and time-consuming national ratification of the MFF by the Member States clearly increases the reform possibilities of the parties. However, the ceiling on spending acts as a counterforce. Article 312 (1) states that the Union expenditure develops within the limits of its own resources and since there is a clear ceiling on the revenues of the Union, i.e. $1.23 \%$ of the GNI, expenses are also under control. Consequently the MFF is the envy, and almost the ideal, for those who want to balance the budget and curtail the growth of governmental budgets.

\section{Flexibility}

As mentioned, the MFF ensures stability in EU spending over time and avoids annual inter-institutional battles as well as battles amongst the Member States (European Parliament 2013). At the same time, however, flexibility is needed to cope with unforeseen budgetary needs. In general this can be achieved by increasing the flexibility instruments in number and/or in terms of the allocated amounts, for instance, or by creating more flexibility in terms of procedural simplicity (Molino and Zuleeg 2011: 15). Flexibility also became an issue in the negotiations about the new MFF. Several routes were taken to address this issue.

\footnotetext{
${ }^{12}$ With regard to the constraining powers of the MFF's formal rules, it is also of importance to look at how Member States are constrained (checks and balances) by internal decision-making processes prior to presentations in country positions at the EU level (Benedetto 2012: 24-28). These constraints, however, are not discussed in this paper.
} 
The MFF package includes an IIA on budgetary discipline, cooperation in budgetary matters and sound financial management (Art. 259 TFEU). It contains provisions related to the special flexibility instruments not included in the financial framework.

Specifically, the new MFF allows unused margins (differences between the expenditure ceilings and the money actually spent) as well as unused funds (unused payment appropriations) to be transferred to the following year or different areas of the budget. In the new MFF it is also possible to move available funds between different areas. The new IIA ensures that the available funds are fully used rather than returned to the Member States, as was the case previously. In short, there is flexibility with regard to both budgeted commitments and actual payments.

In addition to these general instruments some specific flexibility measures have been introduced. For instance, there is more flexibility for commitments in growth and research: the remainder can be used at a later date. There is also special flexibility with regard to youth employment and research. Without being limited by the annual expenditure ceilings set by the MFF funds, money can be brought forward (frontloading). Finally, there is a last resort instrument to react to unforeseen circumstances: a general contingency margin that amounts to $0.03 \%$ of the EU's GNI. ${ }^{13}$

Part of what can be called "the flexibility deal" in the new MFF package is also a revision clause in the existing MFF 2014-2020. Halfway through its time period, the Council, EP and Commission can check whether the political priorities and figures allocated to expenditure ceilings should be revised. This review should take place in 2016 at the latest. It also allows the newly elected EP and Commission (as of 2014) to reassess the priorities for the MFF's remaining years. ${ }^{14}$

\section{Off Budget ${ }^{15}$}

Just as a government, e.g., the state governments of the U.S., can use public authorities to circumvent constitutional debt limits (Bunch 1991: 57), the Union can use the European Investment Bank (EIB) as a sort of financial intermediary, for example. In the U.S. the introduction of fiscal restraints induced the engagement in off-budget activities and authorities (Hagen 1991: 202, cp. Bennett and Dilorenzo 1983).

\footnotetext{
${ }^{13}$ It should be noted also that the overall margin available under the own resources ceiling for payment appropriations is already "used" as collateral for the outstanding loan amounts or credit lines granted to the Member States under the European financial stability mechanism (Marzinotto 2012: 6)

${ }^{14}$ During this midterm review the Commission also has to present a proposal aligning the MFF with the political cycles of the institutions.

${ }^{15}$ According to Art. 310 of the Treaty, all items of revenue and expenditures have to be entered into the budget. This, however, is still far from true. The EU budget acts as "collateral" in a number of financial instruments, e.g. the European Stability Mechanism, loan guarantees to small and mid-size enterprises, and trust funds in development aid. It was the EP's wish to include these items in the new MFF.
} 
Specifically, for the Union this means that some funds or projects are left outside the MFF. These instruments are also available outside the expenditure ceilings agreed in the MFF. They are the Emergency Aid Reserve, European Globalization Fund, Solidarity Fund, Flexibility Instrument and the European Development Fund (EDF). ${ }^{16}$ In short, although debt and/or an increase in expenditures are prohibited in the budget they are not necessarily prohibited off-budget (Blankart 1996: 258).

Lastly, another off-budget payment is on the horizon. Although the MFF was cut in real terms for the first time, the actual result probably will be different. In general, commitments (undertakings to pay) were cut by $3.4 \%$ and payments by $3.7 \%$, i.e. $0.3 \%$ of the EU-wide GNI. ${ }^{17}$ The unusually large gap between these two amounts could cause problems down the line. The EP and the Commission probably think that there will be a future bail-out. In the same way so-called top-up funds were necessary retroactively for the 2013 budget: extra money was needed to pay for the commitments that the Council had agreed to supply.

\section{Conclusion}

The MFF is the necessary and logical complement to the development of a Union that is focused on personal freedom: the freedom to trade in goods and services, the freedom to choose one's country of residence and the freedom of capital movement. It is also the complement to a Union that is devoted, at worst, to finance its redistributive programs or, at best, to provide public goods (Blankart 1996: 257, Blankart and Kirchner 2003: 3). Hence, the original Treaty only needed a few budgetary rules (Articles 310 to 325). After the introduction of these loose fiscal rules, however, a transparent financial framework became necessary. In other words, just fixing the existing budgetary rules was no longer sufficient: institutional-constitutional reform was needed (Buchanan 2000: 213). The MFF was the result.

The new MFF gave more power to the EP. In line with the Commission's desire, that power was used to increase the EU budget. This notwithstanding a reduction that was much heralded by some Member States. The EP and Commission were an effective counterforce to the wish of the European

\footnotetext{
${ }^{16}$ The EDF gives assistance to African, Caribbean and Pacific countries. It is also outside the scope of the MFF because Member States contribute differently to it than how they finance the EU budget.

${ }^{17}$ In general, the budget decreased from $1.12 \%$ of the EU GNI to $1 \%$ (representing the first net reduction of the EU budget in the Union's history). In 2015 a budget of $1 \%$ of the GNI or about $2 \%$ of government expenses equals about 140 billion euro or about 300 euro per EU citizen. Of course this leaves hardly any room for Keynesian inspired EU-wide discretionary fiscal stimulation policy. Thanks to its multiplication effect and its focus on results it has a big impact, though, as the European Commission states. Over 2007-2013 for instance, the average increase in GNI as a result of Cohesion Policy, most notably assistance to the EU's lessdeveloped countries and regions, is estimated at $2.1 \%$ a year in Latvia, $1.8 \%$ a year in Lithuania and $1.7 \%$ a year in Poland (European Commission, May 27, 2015).
} 
Council to curtail the budget. As a result, due to creative bookkeeping, the budget was cut in name only.

This result was more or less to be expected. History shows that when an "outside" agent forces a reduction in government expenses the government will respond by increasing hidden liabilities (Easterly 1999). Flexibility, i.e. more money to spend, was achieved specifically by introducing the possibility to carry-over budget surpluses from one sector to another, commitment appropriations becoming actual payment appropriations, a half term revision, and the creation of off-budget programs.

Although the new MFF budget went down with 30 billion euro overall, the actual spending will increase with the same amount compared to the old MFF due to the increased flexibility in the use of money. Under the old MFF a total of 60 billion euro of unspent money had to be returned to the Member States (European Commission 2013b, Euractiv 2013). However, with the new MFF the whole budget is guaranteed to be spent because of the increased flexibility.

Despite the aforementioned, the new MFF is a logical and necessary addition to the existing fiscal rules. It is fully in line with the Union's growing emphasis on spending. The result of the new MFF package is all but perfect, though, as was to be expected given the experiences elsewhere. It is fraught with transparent budget gimmickry.

\section{References}

Benedetto G (2012) Budget Reform and the Lisbon Treaty. In European Union Budget Reform. Institutions, Policy and Economic Crisis, Benedetto G and Milio S (Eds), Palgrave MacMillan.

Bennett JT, Dilorenzo TJ (1983) Underground government: The off-budget public sector. Washington DC: Cato Institute.

Blankart CB (1996) The European Union's Debt Question: A Conceptional Viewpoint. Constitutional Political Economy 7: 257-265.

Blankart CB, Kirchner C (2003) The Deadlock of the EU Budget: An Economic Analysis of Ways In and Out. CESifo Working Paper No. 989: 33

Buchanan J [1975] (2000) The Limits of Liberty. Between Anarchy and Leviathan. Liberty Fund, Indianapolis.

Bunch BS (1991) The effect of constitutional debt limits on state governments' use of public authorities. Public Choice 68: 57-69.

Campanella E (2011) What constitutional fiscal rule for the members of the EU? VOX.EU February 20, 2011.

Debrun X, Moulin L, Turrini A, Ayuso-i-Casals J, Kumar MS (2008) Tied to the mast? National fiscal rules in the European Union, Economic Policy (April 2008): 299-362.

Dhéret C, Marinovici A, Zuleeg F (2012) The state of play on the EU Multiannual Financial Framework (MFF) 2014-2020 interinstitutional negotiations. European Policy Centre.

Eastery, W. 1999. When Is Fiscal Adjustment an Illusion? The World Bank. Policy Research Working Paper 2109. 
Elster J (2000) Ulysses Unbound. Studies in Rationality, Precommitment, and Constraints. Cambridge: Cambridge University Press.

EurActiv (2013) "Lewandowski: Agreeing the budget was 'extreme sports'", June 28.

European Commission (2011) European Commission proposal for the 2014-2020. Multiannual Financial Framework, European Union (updated version 2012).

European Commission (2013a) The Multiannual Financial Framework 2014-2020--Frequently Asked Questions. Brussels, November 19, 2013.

European Commission (2013b) Consolidated Annual Accounts of the European Union, financial year 2013, Key information.

European Commission (2014) European Union Public Finance. $5^{\text {th }}$ Edition, Luxembourg.

European Commission (2015) Commission proposes draft EU budget for 2016: focus on jobs, growth, migration and global action. Brussels, May 27, 2015.

European Council (2013a) Council Regulation (EU, EURATOM) No 1311/2013 of December 2, 2013 laying down the multiannual financial framework for the years 2014-2020. Official Journal of the European Union December 20, 2013.

European Council (2013b) Interinstitutional agreements European Parliament, Council, European Commission. Interinstitutional Agreement of December 2, 2013. Official Journal of the European Union C 373/1.

European Parliament (2013) Focus: The battle for the EU's long-term budget. Available from: http://bit.ly/1LyKJ2w.

Friedman M, Friedman R (1980) Free to Chose. A personal statement. Harmondsworth: Penguin Books.

Hagen von J (1991) A note on the empirical effectiveness of formal fiscal restraints. Journal of Public Economics 44: 199-210.

Hagen von J, Harden IJ (1995) Budget processes and commitment to fiscal discipline. European Economic Review 39: 771-779.

International Monetary Fund. 2009. Fiscal Rules--- Anchoring Expectations for Sustainable Public Finances. December 16, 2009.

King T (2014) An opaque EU budget cannot be defended, EuropeanVoice, 11.06 .2014

Kopits G (2001) Fiscal Rules: Useful Policy Framework or Unnecessary Ornament? IMF Working Paper 01/145.

Marzinotto B (2012) The Long-Term EU Budget: Size or Flexibility?, Bruegel Policy Contribution, Issue 2012/20, November.

Luechinger S, Schaltegger CA (2013) Fiscal rules, budget deficits and budget projections. International Tax Public Finance 20: 785-807.

Molino E, Zuleeg F (2011) Key Political Messages Regarding the Upcoming EU Multiannual Financial Framework (MFF) post-2013. European Policy Centre. European Union QG-32-13-074-EN-N.

Nello S (2012) The European Union, Economics, Policies \& History. London: McGraw-Hill.

Poterba JM (1996) Do budget rules work? National Bureau of Economic Research, Working Paper 5550.

Schuknecht L (2004) EU fiscal rules. Issues and lessons from political economy. European Central Bank, Working Paper Series, No. 421/December. 